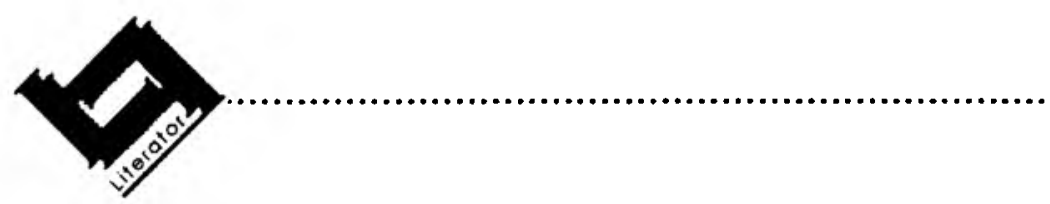

\title{
Die Afrikaans van Engelssprekende universiteitstudente: intertaalperspektiewe
}

\author{
Barbara Bosch \\ Departement Linguistiek \\ Universiteit Rhodes \\ GRAHAMSTAD \\ E-pos: akab@warthog.ru.ac.za
}

\section{Abstract \\ The Afrikaans of English-speaking universlty students: interlanguage perspectives}

This article examines the syntactic performance of English-speaking university students who are learning Afrikaans for academic purposes. The learners ' errors are discussed within the theoretical framework of interlanguage, and special attention is given to the analysis and explanation of these errors. Finally, the advantages and practical implications of teaching Afrikaans to English-speaking university students within a contrastive interlanguage paradigm are discussed.

\section{Inleiding}

Nêrens in die wêreld bevind taalgebruikers hulle in 'n eentalige omgewing nie. Ook in Suid-Afrika met 'n Grondwet waarin vir elf tale voorsiening gemaak word, word niemoedertale (hiema NMT) deur 'n groot verskeidenheid sprekers aangeleer en gebruik. Op verskillende stadia van die taalaanleerproses maak hierdie aanleerders sistematies "foute"' en gebruik hulle afwykings van die standaardvariëteit van die doeltaal. Sedert die verskyning van Corder se seminale 1967-artikel, "The significance of leamers' errors", waarin hy betoog dat die stadia van taalverwerwing op 'n skaal aangedui kan word (De Wet, 1996:165), is

1 In die res van die artikel word aanhalingstekens vermy Die uitgangspunt is dat die leser deurentyd in gedagte sal hou dat foute binne die intertaalparadigma nie normatief benader word nie. 
letterlik honderde empiriese studies oor NMT-aanleer binne die raamwerk van die intertaalteorie onderneem.

Hipoteses oor die konsep intertaal word veral op waargenome taalgebruiksdata gegrond (Bialystok \& Sharwood Smith, 1985:101) en die uitgangspunt is dat indien moedertaalsprekers van taal $A$ daarna streef om 'n nuwe doeltaal aan te leer, 'n aanleerdersvariëteit ${ }^{2}$ wat as 'n intertaalstadium beskou kan word, ontstaan. Die aanleerdersvarieteit kan waargeneem word in die taalaanleerder se linguistiese output wat noodwendig verskil van die taalgebruik van die moedertaalspreker van die doeltaal. 'n Analise van die afwykings wat in die intertaalstadium deur die aanleerder gemaak word, bied insig in die aard van die intertaal. In hierdie konteks is die intertaal 'n verskynsel wat in eie reg bestudeer behoort te word (Corder, 1978:71).

Intertaalperspektiewe het implikasies vir taalverwerwing (Sridhar, 1981:208). In die lig van die pleidooi dat navorsing oor NMT-aanleer waar Engels nié die taal is wat aangeleer word nie, uitgebrei behoort te word (Faerch, 1986:211), is 'n ondersoek gedurende 1995 onderneem na die foute wat deur Engelssprekende eerstejaarstudente in hul gebruik van akademiese Afrikaans ('n "language for specific purposes") gemaak is. Selinker (1984:341-2) stel juis dat navorsingsbevindinge oor taal-vir-spesifieke-doeleindes binne die raamwerk van intertaalteorie besonder insiggewind is. Volgens Taylor (1986:144) kan kennis van die intertaal in gevalle waar die verwerwing van skriftelike vaardighede vir taalaanleerders meer gewig dra as mondelinge vaardighede, 'n waardevolle bydrae tot die "teaching of writing" lewer.

Azevedo (1980:217) bevind dat gevorderde studente veral foute maak met betrekking tot die morfologie, die keuse van voorsetsels en leksikon-items en sintaktiese konstruksies. Die doel van hierdie artikel is om aan die hand van intertaalteorie die sintaktiese foute in die intertaal van volwasse taalaanleerders (in hierdie geval volwasse Engelssprekendes) te ondersoek en te probeer verduidelik.

\section{Die begrip intertaal}

Intertaal is 'n term wat deur Selinker (1972) geskep is om die taalsisteem te beskryf waaroor taalaanleerders beskik gedurende die proses van NMT-aanleer, met ander woorde 'n soort oorgangsvaardigheid of taalaanleerder-taal (Corder, 1981:66; De Wet, 1996:103). Hierdie intertaal is die manifestasie van 'n "coordinated set of systems" wat waarneembaar is in die "systematic language

2 De Wet (1996:1) stel dat 'n aanleerdersvarieteit ontstaan wanneer volwasse sprekers 'n ander taal as hul moedertaal aanleer sodat dit hul doeltaal word. 
performance ... by second-language learners who have not achieved sufficient levels of analysis of linguistic knowledge ... to be identified completely with native speakers" (Bialystok \& Sharwood Smith, 1985:116).

Die intertaalsisteem is veranderlik, heterogeen en dinamies (Ellis, 1985:118), word gekenmerk deur kreatiewe konstruksies (Dulay \& Burt, 1978) en ontwikkel langs ' $n$ kontinuum in die rigting van ' $n$ bepaalde vorm van die doeltaal (Corder, 1978:73). Op enige gegewe stadium van die taalaanleerproses kan die intertaalvorm beskou word as 'n spesiale soort (oorgangs-) dialek met eiesoortige eienskappe (Corder, 1981:14, 18).

Die intertaalkontinuum vertoon eiesoortige kenmerke omdat verskeie tipes beïnvloeding plaasvind - onder andere taaloordrag uit die moedertaal in die taalaanleerproses (Bialystok \& Sharwood Smith, 1985:101; Selinker, 1992:207). Gedurende die proses van NMT-aanleer is die aanleerder besig om bepaalde strukture uit sy/haar moedertaal geleidelik met strukture uit die doeltaal te vervang, of om die moedertaalstrukture te verander sodat dit in ooreenstemming met dié van die doeltaal kom. Hierdie "progressive restructuring" vind op 'n "restructuring continuum" plaas (Corder, 1978:75). Intertaalsprekers se sisteme bevat vorme wat nie in of die doeltaal of hul moedertaal bestaan nie, asook vorme wat wel in die doeltaal voorkom, maar nie dieselfde betekenisse het as in die doeltaal nie (Selinker, 1991:26).

\section{Die begrippe kontras-analise ("contrastive anaiysis") en fout-analise ("error analysis") binne intertaalteorie}

Kontras-analise kan omskryf word as daardie subdissipline binne die taalkunde wat gemoeid is met " ... the comparison of two or more languages (or subsystems of languages) in order to determine both the differences and similarities between them" (Fisiak, 1980:1). Twee tipes vergelykende studies, naamlik teoretiese en toegepaste ondersoeke, kan onderskei word (Fisiak, 1981:2). Binne die raamwerk van toegepaste kontrastiewe vergelyking kan potensiële konflikareas tussen die moeder- en doeltaal vergelykenderwys geïdentifiseer word. Hierdie inligting is veral waardevol in situasies waar die aanleer van die NMT oor 'n lang periode plaasvind (Svartvik, 1973:11) ${ }^{3}$ en kan in 'n onderrigsituasie gebruik word vir die beplanning van leerplanne en ontwikkeling van onderrigmateriaal.

Volgens Selinker $(1992: 102,118)$ dui data verkry uit kontras- en fout-analises (m.b.t. die doeltaalnorm) op die bestaan van 'n intertaal. Die intertaal van 'n taalaanleerder beklee 'n tussenposisie tussen die taalaanleerder se moedertaal en

3 Die 1995 eerstejaarstudente was op skool minstens elf jaar lank aan Afrikaans blootgestel. 
die doeltaal: op enige gegewe tydstip openbaar dit eienskappe van sowel die moeder- as doeltaal. Die taalgebruik van 'n taalaanleerder wat oor 'n tipe intertaal beskik, verskil van dié van die moedertaalspreker, maar is steeds sistematies van aard (Ellis, 1985:118). Daar word aanvaar dat talle aspekte van ons kennis van NMT-aanleer aan die lig gekom het deurdat die foute wat taalaanleerders maak, ondersoek is (McDaniel et al., 1996:32). Hierdie foute, wat volgens ' $n$ bepaalde sisteem gemaak word en dinamies van aard is, funksioneer op enige gegewe stadium as "vensters" op die taalaanleerproses (Corder, 1967, Ellis, 1985:118).

Sedert die middel-sewentigerjare word kontras- en foutanalise binne die intertaalparadigma ondermeem (Celce-Murcia \& Hawkins, 1985:60). Binne hierdie paradigma funksioneer fout- en kontras-analise komplementêr (Corder, 1981:62; Marton, 1981a:165). In hierdie studie word die tipe foute wat gemaak is, binne die raamwerk van kontras-analise nagegaan; ' $n$ benaderingswyse wat reeds in 1945 gepropageer is deur C.C. Fries wat beweer het dat "the most effective (teaching) materials are those that are based upon a scientific description of the language to be learned, carefully compared with a parallel description of the native language of the learner" (Fries, 1945:9).

Ellis (1985:125) argumenteer dat op enige stadium van NMT-aanleer die aanleerder se intertaal saamgestel is uit "competing rules" wat ten opsigte van die moeder- en doeltaal geld. In die lig hiervan beweer Corder (1981:59) dat vertroudheid met sowel die moedertaal van die taalaanleerders as die doeltaal en onderrigervaring van die taalaanleerders wat bestudeer word, voorvereistes is vir die bestudering van ' $n$ intertaal: die doel van die vergelyking van die moeder- en doeltaal is juis om die verhouding tussen die strukture van die moeder- en doeltaal vas te stel (Corder, 1978:75). In die lig van die vergelykende data word dit dan moontlik om die foute te verklaar; dit is volgens Corder (1981:24) die uiteindelike doel van fout-analises.

Die skrywer van die artikel is Afrikaanssprekend, maar is Engels goed magtig en kon dus dit wat die aanleerders in die NMT wou enkodeer, redelik gemaklik identifiseer.

\section{Die ondersoek}

Die databasis (62 000 woorde) vir hierdie studie is die geskrewe werk wat studente gedurende 1995 in die Afrikaans 1 (Professioneel)-kursus 4 in toetse en

4 Studente wat nie Afrikaanssprekend is nie en wat 'n B-simbool of laer vir Afrikaans Tweede Taal verwerf het, word tot hierdie kursus toegelaat. Die kursuskomponente is: Teksstudie, Taalkunde, Taalkommunikasie en Gebruikskunde. 
in die eksamen ingelewer het 5 .

'n Studie van taalgebruikers se geproduseerde taalmateriaal is 'n metode wat uitgebreid gebruik word in ondersoeke na taalaanleerpatrone (McDaniel et al., 1996:xvii; 6). Taalaanleerders, en by implikasie dus ook volwasse aanleerders, verskil noodwendig in die wyse waarop 'n vreemde taal aangeleer word en die soort foute wat gemaak word; gevolglik is besluit om nie net op die taalgebruik van 'n enkele taalaanleerder te fokus nie. Hierdie werkswyse word deur Taylor (1986:147) ondersteun. Taylor (1986:147) stel voorts dat geskrewe data wat in situasies gegenereer word waar die taalaanleerder nie bewus is dat foute per se ondersoek word nie die mees geskikte is vir die identifisering van foute.

Die konteks waarbinne die NMT gebruik word, kan die taalgebruik ("performance") van die aanleerder beïnvloed (Tarone, 1983; Widdowson, 1979). Daar kan aangeneem word dat die studente onder toets- en eksamenomstandighede Afrikaans so korrek as moontlik probeer gebruik het. Daar is besluit om die geskrewe werk wat tuis voltooi is, nie in die databasis op te neem nie, omdat die moontlikheid bestaan dat hierdie werk deur iemand anders taalkundig versorg kon gewees het. Omdat die foute wat in gesproke taal gemaak word, konteks-afhanklike en buitetalige oorsake kan hê, word daar in hierdie studie slegs op geskrewe taal gekonsentreer ${ }^{6}$.

Slegs foute wat by die eerste deurlees van die materiaal deur die ondersoeker geïdentifiseer is, is beskryf; "grensgeval"-foute is buite rekening gelaat en persoonlike voorkeure van die ondersoeker is sover moontlik vermy ${ }^{7}$. Daar word nietemin erken dat die herkenning en interpretasie van die foute wat taalaanleerders maak, problematies kan wees: sekere oênskynlik afwykende taalgebruikspatrone kan aanvaarbaar wees binne 'n bepaalde konteks. Om dié rede, argumenteer Corder (1981:37), is dit nodig dat die taalaanleerder beskikbaar moet wees vir konsultasie. Indien dit nié moontlik is nie, behoort daar gebruik gemaak te word van materiaal waarin van die taalaanleerder verwag word om die idees en standpunte van ander te herformuleer (bv. vertalings, opsommings, die oordra van gestelde inligting) (Corder, 1981:39). Die taalmateriaal wat ondersoek is, het juis van die taalaanleerders verwag om verskafde

$5 \quad$ Volgens Svartvik (1972:12) word eksamenantwoorde uitgebreid in die analise van foute gebruik. Ook De Wet (1996) gebruik eksamendata in haar ondersoek omdat "juis .. akademiese taalbeheersing van belang is" (De Wet, 1996:14) behoort te word. 
inligting te interpreteer, op te som en op 'n sinvolle wyse in sy/haar eie woorde weer te gee.

Daar was 37 studente in die klas; 20 mans en 17 dames. Daar kan aanvaar word dat hierdie studente, wie se moedertaal Engels is, minstens elf jaar lank op skool aan Afrikaans blootgestel was ${ }^{8}$. Die fokus van hierdie studie is op sprekers wat, ten spyte van hierdie blootstelling, nog nie volledig tweetalig is nie, maar wat besig is om in dié rigting te ontwikkel.

In Afrikaans is woordorde belangrik vir die aanduiding van semantiese en sintaktiese verhoudings tussen sinsdele. In die lig van Hatch (1978:59) se bevinding dat woordorde-foute veral deur beginners en gevorderde taalaanleerders gemaak word en omdat verhoudings tussen sinsdele in akademiese taalgebruik belangrik is, word daar in die bespreking wat volg op sintaktiese foute gekonsentreer.

\section{Sintaktiese patrone in die intertaal}

Sintaktiese patrone is een van die areas waar afwykings van doeltaalpatrone die geredelikste voorkom (Dulay et al., 1982:55).

\subsection{Bepalings}

Omdat die volgorde van bepalings in Engels en Afrikaans verskil, en omdat die voorkeurpatroon in taalaanleerstadia onderwerp/voorwerp + bepaling is (Givón, 1984:128), is dit te verwagte dat taalaanleerders intertaal-woordvolgordepatrone sal gebruik.

Hy sal nooit weer in die samelewing normaal kan leef nie ${ }^{9}$

Sy wil 'n apie soos Barnie s'n ook hê

Hy wou die realiteit wat lê buitekant, vermy

Sy voel baie sleg omdat haar pa ook gesterf het twee weke later

In die boetiek is daar spieëls oral

Hy het hulle hoor so sê

Barnie het vir Gertie belowe om sy apie vir haar eendag te wys

Ons sal na die karakterisering nou kyk // Sy was 'n ander persoon nou

Hulle kan in elke plek wêreldwyd kommunikeer

Bostaande voorbeelde ondersteun Givon (1984) se siening en dui aan dat bepalings ook in die intertaal van volwassenes wat Afrikaans vir akademiese

8 Die anderskleurige studente wat lede van die klas was, het op navraag aangedui dat hulle hulself as Engelssprekend beskou.

9 Voorbeelde word woordeliks aangehaal en is nie noodwendig feitelik korrek nie. 
doeleindes aanleer, onmiddellik ná die naamwoord of werkwoord wat omskryf word, voorkom. ( $\mathrm{Vgl}$. in dié verband ook die waarneming van Ponelis [1988: 128] oor tipes inhoudelike reduksie in gebroke tale.)

\subsection{Verbale elemente}

Verskeie soorte woordordefoute wat met die gebruik van werkwoorde en werkwoordelike elemente saamhang, word aangetref.

\subsubsection{Deeltjiewerkwoorde ${ }^{10}$}

Die deeltjie van deeltjiewerkwoorde word verkeerd gebruik, vgl.:

Omdat Doris beweeg weg van die N.G.-kerk ...

Dit sluit in die primêre ... / Dit sluit in neologismes en klanknabootsing // "Gelykenis" insluit 'n reeks van karakters ...

Gerrit uitdaag die ander ...

In die eerste voorbeeld, dus ná 'n onderskikkende voegwoord (=omdat) behoort die deeltjie nie van die werkwoordelike element geskei te word nie. In die voorbeelde met insluit en uitdaag, waarin 'n subjek (= "Gelykenis"/Gerrit) of voorlopige subjek $(=d i t)$ optree, behoort die deeltjie ná die objek te volg.

Dit wil voorkom asof daar in hierdie voorbeelde veral sprake is van taaloordrag uit die moedertaal; taalaanleerders is waarskynlik besig om bepaalde strukture uit sy/haar moedertaal geleidelik te vervang met strukture uit die doeltaal, of om die moedertaalstrukture te verander sodat dit in ooreenstemming met dié van die doeltaal kom.

\subsubsection{Hulpwerkwoorde}

Hulpwerkwoorde van vorm en tyd, asook modale hulpwerkwoorde, word of op die verkeerde plek in die sin gebruik, of word heeltemal weggelaat. Dit gebeur in positiewe sinne, asook in sinne waarin negatiewe partikels optree:

Doris het besluit dat sy sal nie net by die huis bly nie

Ongelukkig Piet word gesond...

Deur tweetaligheid sal die lewens van die betrokkenes verryk ()

Haar pa het nie daarvan gehou dat Doris gerook ( ) nie

Doris het 'n nuwe lewe en baie verander het

... gevolglik kon hy nie meer gewerk () nie // kon hy nie meer werk nie

10 Volgens Ponelis (1979:232) is 'n deelfiewerkwoord 'n baie hegte verbinding van 'n werkwoordelike element met 'n ander element - die deeltjie - sodat die werkwoordelike element en die deeltjie saam 'n leksikale eenheid, 'n hoofwerkwoord, vorm. 
... sodat die man moet haar ontmoet

... maar wou dit nie hê nie

... omdat die taal kan meer verstaanbaar wees

Soos wat die geval is wanneer deeltjiewerkwoorde gebruik word, is moedertaalinvloed merkbaar in taalaanleerders se intertaal wanneer hulpwerkwoorde gebruik word.

\subsubsection{Infinitief}

Die infinitief word nie ooreenkomstig die struktuurreëls van Standaardafrikaans gebruik nie.

- Een, of albei die infinitiefpartikels (om te) word weggelaat - vgl :

Sy het ook begin () kerk toe te gaan

Die briefskrywer het probeer om sy lewe veilig gemaak (i.p.v. te maak)

... sal mense ook help ( ) 'n beter begrip van die Afrikaner te kry

Al twee groepe het die "nuwe" taal gebruik om te handel en () kommunikeer

Mense kry die geleentheid om ... te doen en () geniet.

Dit help twee verskillende kulture ( ) vir mekaar te verstaan en ( ) ( ) kommunikeer

Hy is bang om dinge in die gesig ( ) kyk en hulle probeer om te verander

Sy weet nie wat om met die woorde/leuens moet doen (i.p.v. te doen)

Hoewel sommige van hierdie konstruksies as 'n tipe hendiadis-konstruksie aanvaarbaar sou kon wees, is dit problematies in 'n akademiese konteks.

- Indien die infinitief in kombinasie met deeltjiewerkwoorde gebruik word, word die deeltjiewerkwoord as onskeibare werkwoord gebruik:

Woordeboeke word gebruik om woorde te naslaan

Die rol van 'n woordeboek is om vertalings te aandui

Hy probeer om alles neerskryf...

- Indien 'n modale hulpwerkwoord egter gebruik word, word die deeltjiewerkwoord geskei en word die modale hulpwerkwoord tussen die twee dele geplaas:

Die fliek handel oor 'n vrou wat weg wil breek

- $\mathrm{Na}$ behoort word 'n foutiewe infinitief-konstruksie gebruik:

Die streektaal behoort net in daardie deel van die land te gebruik 
- In kombinasie met die negatief word die negatief-partikels weggelaat, op die verkeerde plek in die sin gebruik en soms word 'n oortollige negatief-partikel aangetref:

Niemand help haar om te verstaan ()

Die joernalis is nie bang nie om hierdie wêreld te verlaat en die ander ( ) besoek ()

Hy is nie sterk genoeg nie om sy seun self te gaan besoek nie

- 'n Oorbodige infinitief-partikel of infinitiefvorm word aangetref - vgl:

Dit laat 'n mens om verskeie tale te leer

... wanneer 'n taal soos Engels 'n invloed op Afrikaans $h \dot{e}$

\subsubsection{Passief-konstruksies}

Ten spyte van Ponelis (1988:128) se bewering dat passief-konstruksies nie in aanleerdervariëteite voorkom nie, gebruik Engelssprekende universiteitstudente wel die passief. Hulle ervaar egter probleme met die vorm van die werkwoord in Afrikaanse passief-konstruksies:

Die taal het 'n Afrikaanse basis en is in stede gevind

Tans is dit meestal gebruik deur mans

In die verlede was dit gesien as die taal van ...

Pidgin-tale is gekenmerk deur ' $\mathrm{n}$ vereenvoudiging van ...

Daar is baie informasie wat in woordeboeke gevind is

Die taal is nog steeds vandag gepraat

Spraakklanke is deur die organe in die mond en keel gevorm

\subsection{Voegwoorde}

- Hoofwerkwoorde en medewerkwoorde word in geïnkorporeerde sinspotente groepe" 11 nie in die sinsfinale posisie aangetref nie:

Hulle is bang dat hulle maak 'n fout $/ / \ldots$ dat dit skep probleme vir vertalers en tolke // Hy het gesê dat Tank was 'n kommunis // Gertie sien dat Doris het verander // Die nadele is dat ... is dit baie duur

- Die sintaktiese vereistes vir die gebruik van 'n partikel as voegwoord en as voegwoordelike bywoord in Afrikaans word verwar. Die gevolg hiervan is dat

11 Sinspotente groepe is groepe wat bestaan uit een verbale element en en subjek wat volgens 'n aanvaarbare struktuurpatroon saangestel is, en wat die vermoe het om as selfstandige eenheid (dominante groep) op te tree, maar wat in bepaalde sintaktiese omstandighede in 'n groter eenheid geinkorporeer word (inkorporasies/geinkorporeerde sinspotente groepe). Vir 'n uitgebreide bespreking van die begrippe, kyk Bosch, 1993). 
'n partikel wat as voegwoordelike bywoord funksioneer, gevolg word deur die woordordepatroon wat na 'n voegwoord aangetref sou word:

Alhoewel die meeste van die taalmateriaal behoort aan die standaardtaal Daarom in 'n taalgebied waar daar moedertaalsprekers wees

Dus die Afrikaanse woordeskat was veral deur Engels beïnloed // Dus tweetaligheid in die konteks van Suid-Afrika sluit voordele sowel as nadele in // Dus pidgintale vervul die behoefte aan kommunikasie

- Indien meer as een voegwoord saam gebruik word, en een van die voegwoorde nie eksplisiet aanwesig is nie, word die woordvolgordepatroon wat normaalweg ná die aanwesige voegwoord voorkom, gehandhaaf - vgl.:

... omdat die woordeboekmakers ook net menslik is en ( ) kan maklik foute begaan ...

Die meeste taalopvoeders sê dat anglisistiese taal sleg is en ( ) bevorder swak kommunikasie.

... want hulle is bang dat hulle die verkeerde woorde sal gebruik of ( ) selfs 'n anglisisme

- Negatief-aanduiding in komplekse sinne is problematies. Die tweede negatiefpartikel kan of op die verkeerde plek staan of heeltemal weggelaat word:

Affikse het nie betekenis nie as hulle op hulle eie staan

Affikse kan nie alleen staan nie, omdat dit geen betekenis het, op sy eie nie

Hulle is bekommerd dat hulle nie die korrekte woorde gebruik ()

As die hoorder nie die boodskap verstaan () is dit nie goeie kommunikasie nie.

... omdat 'n mens nooit werklik al die tale kan aanleer ( )

... omdat hulle is nie seker of hulle...

Sy het besef dat dit was nie reg nie

Doris het vir Gertie gesê dat sy moenie haar oupa vertel nie dat sy rook

Piet het vir Doris laat verstaan dat sy nie 'n reg tot geluk het ()

Uiteindelik weet die skrywer van die brief dat alles sal nie keer nie

Dit is nie moontlik om Ponelis (1988:128) se waarneming dat aanleerdersvariëteite 'n "relatiewe armoede aan onderskikkingskonstruksies" openbaar, te ondersteun of te verwerp nie. Dit is nodig dat kwalitatiewe navorsing, met ander woorde navorsing oor hoe individuele taalaanleerders onderskikkingskonstruksies gebruik, onderneem word.

\subsection{Voorsetsels}

Taalaanleerders fouteer met betrekking tot die keuse van voorsetsels, setselskeiding en die sinsposisie van die voorsetselgroep - vgl.:

... as hulle in die geselskap met 'n taalkundige is

... en $m e t$ 'n diagram sal dit makliker wees ... 
Hulle word aangekoppel met ... (fixed to)

Al hierdie dinge is belangrik met die aanleer van 'n vreemde taal

Taal kan in twee maniere beskryf word

Piet was baie betrokke aan sy nuwe werk

Doris het nie van dit (= daarvan) gehou nie

Pai het nie van dit gehou nie.

Sy het skuldig oor dit (= daaroor) gevoel

Soos uit die bogenoemde voorbeelde blyk, is voorsetselfoute dikwels die gevolg van moedertaal- (in hierdie geval Engelse) invloed: die Engelse voorsetsel word direk vertaal en die Engelse woordordepatroon word gehandhaaf.

\subsection{Lidwoorde}

Engelse invloed op die gebruik van lidwoorde in Afrikaans kan die volgende uitwerking hê: weglating van die bepaalde of onbepaalde lidwoord waar die Afrikaanse taalstruktuur dit vereis, of toevoeging van die lidwoord waar 'n lidwoord in Afrikaans oorbodig is (Carstens, 1991:63).

Weglating van die lidwoord:

() woordeskat verander mettertyd

Piet het 'n ongeluk by ( ) werk gehad

Toevoeging van die lidwoord:

Hulle is van die mening dat ...

'n Voorbeeld is die gesinstaal

\subsection{Negativering}

Uiteenlopende "afwykende" negatief-konstruksies kom in die intertaal voor.

- Die posisie van die eerste negatief-partikel is afwykend:

Dit is nie net die kinders wat van hom nie hou nie (= wat nie van hom hou nie)

Sy het alles gedoen wat sy moes nie gedoen het nie

Oupa wil Gertie verander in iets wat sy is nie

Die probleme ontstaan hoofsaaklik wanneer die negatief in betreklike konstruksies gebruik word.

- In dominante en geïnkorporeerde sinspotente groepe word die tweede negatief-partikel weggelaat:

Hy is alles wat Piet ( ) is nie

Hy het geen takt ()

Hy wou nie vrede in die kamp hê () 
Daar was geen tyd vir jol ()

Piet wou nie hê dat Doris werk ( )

Hulle kan nie ... as woorde funksioneer ( )

Daarom kan ons sien dat suiwer taal ... nie noodwendig tot goeie kommunikasie lei ( )

- In kombinasie met die negatief vind onaanvaarbare weglating van elemente plaas:

Daar is baie onsekerheid oor wat anglisistiese taal is en () nie

Sy word 'n stil vrou wat nie meer met haar vriende praat ( ) en nooit weer Barnie wil sien nie

\subsection{Betreklike konstruksies}

- Taalaanleerders gebnuik verkeerde betreklike voomaamwoorde of laat die betreklike voornaamwoord verkeerdelik weg:

Suiwer taal is die norm waarby die Afrikaanse establishment ' $n$ mens beoordeel ... die dienspligtige wie die brief skryf // Hy verskil van Tank wie 'n liberaal is

... die prinsipaal van 'n skool of iemand anders ( ) belangrik ( ) (Afr. = wat belangrik is)

Sy het 'n dogtertjie, Gertie, wie het haar ma lief

... daarin is al die terme ( ) iemand wil weet

- In plaas van bywoordelike betreklike voornaamwoorde, word sintaktiese konstruksies gebruik:

Toe Doris van dit (= daarvan) uitvind

In die onderstaande voorbeeld word 'n bywoordelike betreklike voornaamwoord wel gebruik, terwyl 'n sintaktiese konstruksie meer aanvaarbaar sou wees:

Barnie het 'n apie gehad en Gertie het daarvan (= van dit/hom) gehou

- Die verbale elemente wat in kombinasie met die betreklike voomaamwoorde gebruik word, is of onaanvaarbaar, of staan op die verkeerde plek in die sin:

... die betekenisse van die woorde wat die meeste gebruik is

Die manier waarop dit gebruik is ...

... wat 'n sterk Russiese beïnvloeding het

Anglisistiese taal is taal wat deur ander tale beïnvloed ()

Ons gebruik woorde wat ons dink sal mense oorreed

Almal wat praat Afrikaans.. 
- Die sinsposisie van bepalings wat in kombinasie met betreklike voornaamwoorde gebruik word, is onaanvaarbaar:

Dit het die meeste van die kenmerke wat bespreek is hierbo

Daar is spesifieke aspekte van menslike taal wat maak dit uniek

\subsection{Vergelykingskontruksies}

Vergelykingskonstruksies, ook dié waarin negatief-partikels voorkom, is problematies:

Die studente is minder as hom

Die tweede rede is die belangriker van die redes

Die twee mees belangrike is ..

Jy sal nie dieselfde dialek gebruik wanner jy met jou maats praat as terwyl jy met die skoolhoof praat ( )

Daar is baie meer voordele as wat daar is nadele van tweetaligheid

Doris is meer hartseer, maar meer wys

As kan gesien word...

Ondat hulle die politieke en ekonomiese sterker van die twee groepe was, ...

Vergelykingskonstruksie plus negatief-partikels:

Gertie verstaan nie die verandering nie, soos ons in die boek sien

Volgens Ponelis (1988:128) ontbreek adjektiwiese graadfleksie in aanleerdervariëteite. Die struktuur van Engelse vergelykingskonstruksies speel waarskynlik ook ' $\mathrm{n}$ rol in die ontstaan van afwykende vergelykingskonstruksies.

\section{Verduideliking van afwykende sintaktiese patrone in die intertaai}

In ' $n$ intertaalkonteks waar die moeder- en doeltaal op 'n ontwikkelingskontinuum vergelyk word, bied die intertaal 'n moontlike verduideliking van die foute wat deur taalaanleerders gemaak word: in vergelyking met die doeltaal kan die intertaal beskou word as 'n vereenvoudigde weergawe van die doeltaal wat gekenmerk word deur minder komplekse kodes en sisteme as dié in die doeltaal (Corder, 1981:81). In dié verband dui navorsing daarop dat sintaktiese intertaalpatrone dikwels die gevolg is van die invloed van die aanleerder se moedertaalpatrone (vgl. in dié verband onder andere Pienemann, 1981; Gilsan, 1985; Trévise, 1986). 


\subsection{Direkte vertaling van moedertaalstrukture}

Sommige intertaalpatrone ontstaan deurdat 'n moedertaalpatroon direk vertaal word, vgl::

Standaardtaal is gevorm (= is formed) wanneer ...

Die handelaars was in mag (= in power) // Hulle was kwaad met mekaar // Piet wou ... agter sy vrou kyk

... 'n woordeboek bestaan uit 'n lys woorde en wat hulle beteken (= what they mean)

Vreemde elemente kan ook in 'n taal kom (= come into)

$\mathrm{Hy}$ is vol van onsekerheid en twyfel // 'n soort van groepsidentiteit // ... 'n reeks van karakters

As gevolg van moedertaalinvloed, kom daar 'n konstruksie in die intertaal voor wat nié in die doeltaal aangetref word nie.

\subsection{Oorveralgemening}

'n Bepaalde patroon wat in die doeltaal voorkom, word analogies uitgebrei na ander omgewings en in die proses word 'n intertaalstruktuur, wat die resultaat van oorveralgemening is, geskep. In die onderstaande voorbeelde word elemente wat in ander kontekste weggelaat sou kon word, "foutiewelik" weggelaat sodat 'n elliptiese intertaalstruktuur wat moedertaalinvloed weerspieel, maar wat nie in die doeltaal aanvaarbaar is nie, ontstaan:

Hierdie () vorm die passiewe woordeskat

'n Pidgintaal ontstaan wanneer ' $n$ inheemse taal in kontak kom met ( ) handelstaal

Woordeboeke wat oor die geskiedenis van woorde handel bestaan en veeltalige woordeboeke ()

Hy het skaars met sy dogtertjie gepraat en () () met sy vrou gestry

Piet het asma gekry en () () nie meer werk nie

Hy is 'n sagte mens en () vir Mavis versorg

Gerrit gee die bevele en () () nie die swart kinders respek ()

\subsection{Oorvereenvoudiging}

Een van die strategiee wat NMT-aanleerders gebruik, is om die sisteem van die doeltaal te vereenvoudig (Selinker, 1972:219; Selinker, 1987:21). Hierdie vereenvoudiging kan onder andere die weglating van lidwoorde en die foutiewe gebruik van meervouds- en verledetydsvorme insluit (Coulter, 1968:22-36). Die volgende voorbeelde van die vereenvoudiging van Afrikaanse sintaktiese strukture is aangeteken

Dit het ( ) meeste van die kenmerke ...

Daar is oorerwing uit ( ) literatuurtaal, seemanstaal en ... 
Toe Piet weg was, het Doris saam met Barnie ... na 'n dans gegaan het.

... het ontstaan toe koloniste in aanraking met die inheemse bevolking gekom ( ) // Gerrit het baie kwaad geword as die studente nie na hom geluister ( ) nie // Sy dink dat dit haar fout was omdat sy die pomp vergeet () (het ontbreek)

In Europa is daar op verskillende plekke dieselfde gebeur

Die gedig is deur Ingrid Jonker geskryf word

Dit handel oor 'n spesifieke dinge

Al hierdie woordeboek ...

... twee verskillende kultuur

Woordeboeke is ' $n$ nuttige hulpmiddel ...

... drie soort woordeboeke

Pidgintale is nie ' $n$ moedertaal nie

'n woorde se spelling

een moontlikhede

In hierdie ondersoek is die gebrek aan getalskongruensie tussen bepalers en substantiefvorme opvallend. Hierdie bevindings is in ooreenstemming met navorsing wat daarop dui dat die weglating van grammatiese morfeme (bv. meervoudsmerkers) ' $n$ tipe fout is wat in taalaanleerders se mondelinge en geskrewe taalgebruik voorkom (vgl. in dié verband Dulay et al., 1982:55; Ponelis, 1988: 128)

\section{Die onderrig van Afrikaans aan Engelssprekende universiteitstudente binne 'n kontrastiewe intertaal- paradigma}

$\mathrm{Na}$ aanleiding van die tipe foute wat deur taalaanleerders gemaak is, wil dit voorkom of die intertaalstrukture die gevolg is van die prosesse van moedertaalinmenging, analogiewerking en oorvereenvoudiging omdat die taalaanleerder sy/haar kennis van bepaalde NMT-strukture uitbrei na areas waar dit nie geld nie.

Die intertaalparadigma bied 'n vrugbare perspektief op die onderrig van NMTe. Die aanvaarding dat die intertaal dinamies, vloeibaar en veranderlik is, moet noodwendig die onderrig van NMTe beïnvloed. 'n Verduideliking van die soort foute wat deur taalaanleerders gemaak word, het pedagogiese waarde deurdat dit riglyne bied vir die areas waarop daar in suksesvolle NMT-onderrig gekonsentreer behoort te word en aandui hoe die geidentifiseerde areas onderrig sou kon word. Volgens De Wet (1996:165) is dit veral die intertaalkenmerke op grammatikale vlak waarvan die tweedetaaldosent bewus moet wees sodat die remediëring daarvan in taalprogramme geïnkorporeer kan word. Selfs net die wete dat ' $n$ bepaalde struktuur nie in die taalaanleerder se moedertaal voorkom nie, is waardevol in die identifisering van probleemareas (Sanders, 1981:23). 
Die insig dat die intertaal van volwasse taalaanleerders langs 'n bepaalde ontwikkelingskontinuum beweeg (vgl. in dié verband Corder, 1981:94), impliseer dat die onderrig van die patroonmatigheid van die doeltaal ook langs 'n bepaalde kontinuum in die rigting van die uiteindelike verwerwing van doeltaalnorme gestruktureer behoort te word. In dié verband bied die foute wat taalaanleerders maak waardevolle terugvoering in die taalaanleerproses: enersyds leer taalaanleerders uit hul foute, maar andersyds is foute belangrike rigtingwysers vir leerplanontwikkeling en die ontwerp van onderrigmateriaal vir NMT-aanleerders.

$\mathrm{Na}$ aanleiding van die analise van foute wat deur die taalaanleerder gemaak word, kan bepaal word presies wat die aard van die "strukturele botsing" van die moeder- en NMT is. Hierdie insigte kan ' $n$ verantwoorde aanpassing van leerplanne tot gevolg hê wat noodwendig daartoe sal lei dat taalonderrig bevorder word.

In 'n poging om doeltaalvaardighede te bemeester, behoort leerplanne en dus ook die taalmateriaal waaraan taalaanleerders blootgestel word, aangepas te word. Brumfit (1984:316) is van mening dat in die geval van taalaanleerders wat reeds oor 'n redelike mate van taalvaardighede in die doeitaal beskik, die leerplan uitsluitlik rondom waargenome foute gekonstrueer behoort te word. In hierdie konteks behoort dit vir die ervare onderwyser/es moontlik te wees om, vergelykenderwys, probleemareas te identifiseer, om prioriteitsareas met betrekking tot bepaalde taalvaardigheidsvlakke te identifiseer en om geskikte onderrigmateriaal te ontwikkel. In dié verband is vertalingsoefeninge wat op grond van kontras-analise van die doel- en moedertaal ontwikkel is, gepas vir 'n gevorderde vlak van taalonderrig omdat hierdie leerders dikwels gekenmerk word deur "syntactic rigidity and fixedness in their performance in the target language" (Marton, 1981b:182). Om by hierdie studente 'n groter mate van soepelheid in hul gebruik van sintaktiese strukture in die doeltaal te bewerkstellig, "the performance of syntactic and semantic paraphrases of target language sentences should be highly recommended" (Marton, 1981b:182).

Daar behoort nie net op die areas waar die moeder- en die doeltaal verskil, gekonsentreer te word nie, maar strukturele ooreenkomste tussen die moeder- en doeltaal behoort ook aangedui te word. Deur hierdie werkswyse te volg, sal taalaanleerders die geleentheid hê om uitgebreid aan strukturele verskille tussen hul moeder- en doeltaal (areas dus waar negatiewe oordrag uit die moedertaal moontlik sou kon wees) blootgestel te word. Verder behoort taalaanleerders ook deel gemaak te word van situasies waar die sinvolle gebruik van die "problematiese strukture" noodsaaklik is. 


\section{Ten slotte}

'n Analise van die foute wat NMT-aanleerders maak, is van waarde in taalonderrig en noodsaak volgehoue navorsing (Sanders, 1981:30).

Die bostaande ondersoek was slegs gerig op Afrikaans wat vir spesifieke doeleindes ("language for specific purpose") aangeleer word. Om 'n duideliker beeld te kry van die intertaal van volwasse Engelssprekendes en die wyse waarop Afrikaans deur hulle aangeleer word, is 'n meer omvattende opvolgondersoek van die Afrikaans wat deur volwasse Engelssprekendes gebruik word, noodsaaklik. Sodanige navorsing behoort egter ook taalgebruik in ander kontekste (bv. mondelinge data, minder formele geskrewe Afrikaans) in te sluit. Op dié manier sal lig gewerp word op die verskillende onderafdelings van die Engelssprekende aanleerder van Afrikaans se totale intertaalvermoë.

\section{Bibliografie}

Azevedo, M.M 1980. The interlanguage of advanced leaners: an error analysis of graduate students' Spanish. IRAL, 18(3):217-227

Bialystok, Ellen \& Sharwoord Smith, Michael. 1985 Interlanguage is not a state of mind: An evaluation of the construct for second-language acquisition. Applied Linguistics, 6(2)101-117.

Bosch, B. 1993. Sinstipologie: 'n alternatiewe perspektief. Suid-Afrikaanse Tydskrif vir Taalkunde, Supplement 17.

Brumfit, C. 1984. Theoretical implications of interlanguage studies. In: Davies, A., Criper, C. \& Howatt, A.P.R. Interlanguage. Edinburgh : Edinburgh University Press. p. 312-323

Carstens, W.A.M $1991^{2}$. Norme vir Afrikaans. Pretoria : Academica.

Celce-Muria, M. \& Hawkins, B. 1985. Contrastive analysis, error analysis and interlanguage analysis In: Celce-Muria, M. (ed.). Beyond basics: Issues and research in TESOL. Rowley, Mass. : Newbury. p. 60-77.

Corder, S.P. 1967. The significance of leamers' errors. International Review of Applied Linguistics (IRAL), 5(4):161-170.

Corder, S.P. 1978. Language-learner language. In: Richards, Jack C. Understanding second and foreign longuage learning. Rowley, Mass : Newbury House Publishers. p. 71-93.

Corder, S.P 1981. Error analysis and interlanguage. Oxford : Oxford University Press.

Coulter, K. 1968. Linguistic error-analysis of the spoken English of two native Russians. Washington : University of Washington. (M.A. dissertation.)

Davies, A., Criper, C. \& Howatt, AP. 1984. Interlanguage Edinburgh : Edinburgh University Press.

De Wet, A.S. 1996. Swartafrikaans as 'n aanleerdersvariëteit in die Vrystaat: 'n studie aan die hand van intertaalteorie. Bloemfontein : UOVS. (Ph.D.-proefskrif)

Dulay, H. \& Burt, M. 1978. Some remarks on creativity in language acquisition. In: Ritchie, W. (ed.). Second language acquisition research. New York : Academic Press. p.5-89

Dulay, H., Burt, M. \& Krashen, S. 1982. Language two. New York, Oxford : Oxford University Press.

Ellis, Rod. 1985. Sources of variability in interlanguage. Applied Linguistics, 6(2):118-131

Faerch, C 1986. One learner - two languages. In: House, J. \& Blum-Kulka, S. (eds). Interlingual and intercultural communication: Discourse and cognition in translation and second language acquisition studies. Tubingen : G Narr. p. 21 1-227. 
Fisiak, J (ed) 1980. Theoretical issues in contrastive linguistics. Amsterdam : John Benjamins

Fisiak, J. (ed.). 1981. Contrastive linguistics and the language teacher. Oxford : Pergamon Press

Fries, C.C. 1945. Teaching and learning English as a foreign langwage. Ann Arbor : University of Michigan Press.

Gilsan, Eileen. 1985. The effect of word order on listening comprehension and pattern retention: an experiment in Spanish as a foreign language Language Learning, 35:443472.

Givón, Talmy 1984 Universals of discourse structure and second language acquisition. In: Rutherford, William (ed.) Universals in second language acquisition. Amsterdam . John Benjamins.

Hatch, E. 1978. Acquisition of syntax in a second language. In: Richards, Jack C. Understanding second \& foreign language learning. Rowley, Mass. : Newbury House Publishers. p. 34-70.

Marton, Waldemar. 1981a. Pedagogical implications of contrastive studies. In: Fisiak, J. (ed.). Contrastive linguistics and the language teacher. Oxford : Pergamon Press p. 157-170.

Marton, Waldemar 1981b. The pedagogical use of contrastive studies. In: Fisiak, J (ed) Contrastive linguistics and the language teacher. Oxford : Pergamon Press. p. 171-183.

McDaniel, D., McKee, C. \& Smith Caims, H. (eds) 1996. Methods for assessing children's syntox. Cambridge, Mass. : The MTT Press.

Pienemann, Mannfred, 1981. Der Zweitspracherwerb auslandischer Arbeiterkinder. Bonn : Bouvier Verlag Herbert Grundmann.

Ponelis, F. 1979. Afrikaanse sintaksis. Pretoria : Van Schaik.

Ponelis, F. 1988. Afrikaans en taalversteuring. Tydskrif vir Geesteswetenskappe, 28(2):119149

Sanders, C. 1981. Recent developments in contrastive analysis. In: Fisiak, J. (ed.). Contrastive linguistics and the language teacher. Oxford : Pergamon Press. p. 21-32.

Selinker, L. 1972. Interlanguage. IRAL, 10:209-231

Selinker, L. 1984. The current state of $\mathrm{LL}$ studies. In: Davies, A., Criper, C. \& Howatt, A P.R Interlanguage. Edinburgh : Edinburgh University Press. p. 332-343.

Selinker, L. 1987. Interlanguage. In: Nehls, Dietrich (ed ). Interlangwage studies Heidelberg Julius Groos. p. 11-33.

Selinker, L. 1991. Along the way: Interlanguage systems in second language acquisition. In Malave, LM. \& Duquette, G. Language, culture and cognition. Great Britain Multilingual Matters

Selinker, Larry. 1992. Rediscovering interlanguage. London/New York : Longman.

Sridhar, S.N. 1981. Contrastive analysis, error analysis and interlanguage In: Fisiak, J. (ed) Contrastive linguistics and the language teacher. Oxford : Pergamon Press p. 207-241

Svartvik, Jan. (ed.). 1973 Errata. Papers in error analysis. Lund : CWK Gleerup Bokförlag

Tarone, E. 1983. On the variability of interlanguage systems. Applied Linguistics, 4(2): 142163.

Taylor, G. 1986. Errors and explanations Applied Linguistics, 7(2): 144-166

Trévise, Anne. 1986. Is it transferable, topicalization? In: Kellerman, E. \& Sharwood Smith, M. Crosslinguistic influence in second language acquisition. New York : Pergamon Press. p 186-206.

Widdowson, H.G. 1979. The significance of simplification. In: Widdowson, H G. Explorations in Applied Linguistics. Oxford : Oxford University Press. p. 182-201. 